\title{
Improving Savings, Health, and Happiness by Making Small Modifications to Your Community ${ }^{1}$
}

\author{
Randall A. Cantrell ${ }^{2}$
}

\section{Quick Facts}

- The negative effects noise has on citizens' feelings of well-being in their community are a well-known concern (U.S. EPA, 1977).

- Crime-watch systems in $83 \%$ of neighborhoods studied showed a favorable effect on crime (Bennett, Holloway, \& Farrington, 2006).

- School administrators believe school violence affects approximately two-thirds of U.S. students (Garcia, 2003).

- The majority of students (54\%) attending schools that take preventive actions to reduce deviant behavior indicate that they feel safer in school as a result (Garcia, 2003).

- Community-sponsored events have the highest impact when they bring citizens together who otherwise may not meet one another (Guetzkow, 2002).

- Only one-fourth of adults routinely achieve a recommended level of at least 30 minutes of physical activity each day (Ham, Kruger, \& Tudor-Locke, 2009).
Overall community performance: How well the neighborhoods, public schools, and public services address citizens' needs and desires

Recreation: Measures taken to provide convenience to a community's citizens

Ordinance: A law passed by a municipal government

Security: Measures taken to help citizens feel safer in their community

Supplemental programs: Activities sanctioned by schools that occur during non-instructional hours

School outreach activities: Programs intended to increase the public's involvement in schools

\section{Keywords}

Community performance, citizen behaviors, neighborhoods, public schools, public service

\section{Terms to Help You Get Started}

Community: The neighborhoods, public schools, and public services found in a specific area

1. This document is FCS3314, one of a series of the Department of Family, Youth and Community Sciences, Florida Cooperative Extension Service, Institute of Food and Agricultural Sciences, University of Florida. First published May 2013. Please visit the EDIS website at http://edis.ifas.ufl.edu.

2. Randall A. Cantrell, assistant professor, Department of Family, Youth and Community Sciences; Florida Cooperative Extension Service, Institute of Food and Agricultural Sciences, University of Florida, Gainesville, FL 32611.

This material was prepared with the support of the University of Florida. However, any opinions, findings, conclusions, or recommendations expressed are the author(s) and do not necessarily reflect the views of the University of Florida. 


\section{Overall Community Performance and How It Affects Your Family}

Imagine two communities identically modeled after one another and located in the same geographic area. Even if most everything about these communities is the same, they most likely will not perform at the same level of overall effectiveness. The reason for this variation is that inherent differences exist in the daily living behaviors of the two communities' citizens. Even if the citizens' behaviors are the same, the overall performance of the community will not necessarily be the same because of the different practices of each community's governing officials. Thus, citizen behavior is only one part of each community's overall performance, but it is a large part. People are raised and trained in different ways, based on different faiths, morals, ethnicities, habits, genders, etc., so it is expected that they will not conduct their affairs in the exact same fashion as their neighbors.

This series of EDIS publications introduces readers to the concept of overall community performance and suggests minor modifications to neighborhoods, public schools, and public services that could help citizens improve their overall community performance. This publication is intended for an academic audience and condenses all of the information into one publication. The other three publications in this series contain information for a general audience. They include the following:

- Improving Community Performance by Re-examining the Neighborhood (http://edis.ifas.ufl.edu/fy1372)

- Improving Community Performance by Re-examining Public Schools (http://edis.ifas.ufl.edu/fy1374)

- Improving Community Performance by Re-examining Public Services (http://edis.ifas.ufl.edu/fy1373)

The community-performance literature comprehensively addresses community development modifications that citizens can consider. However, there is a need to reexamine and expand the definition of what constitutes improvements in overall community performance. Specifically, items related to minor modifications to neighborhoods, public schools, and public services need to be considered holistically. Unfortunately, many of these items involve some element of comfort and routine, which is the reason that effecting change in citizens' behaviors continues to pose challenges. Figure 1 depicts a conceptual framework for overall community performance.

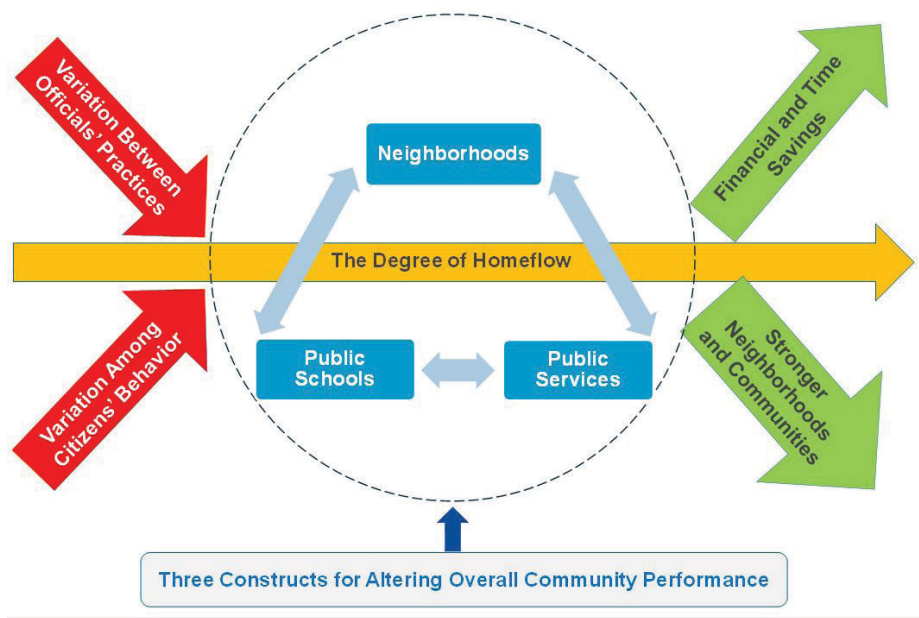

Figure 1. Conceptual framework for overall community performance. Credits: Cantrell \& Stafford, 2013

\section{Overall Community-Performance}

\section{Framework}

1. Two inputs (causes) $=$ Variation between officials' practices and variation among citizens' behaviors

2. Three constructs for altering overall community performance $=$ Minor modifications to neighborhoods, public schools, and public services

3. Two outputs (results) = Improved financial and time savings, and stronger neighborhoods and communities

\section{How Might Your Family Benefit by Improving Overall Community Performance?}

The concept of overall community performance has much to do with re-thinking how people can be happier, which is not the same as being comfortable. Finding ways to keep people living next to one another in the same community and in a relatively peaceful state is not an easy task. Having the ability to reach agreements rather than spending time and money resolving disputes is an attainable goal and one worthy of pursuit.

Financial and Time Savings. If families focus on the various factors comprising their overall community performance, families might realize financial savings and have more discretionary time. However, these potential realities accrue in small increments and often require time before results are noticeable.

Stronger Neighborhoods and Communities. One goal of examining the concept of overall community performance is to develop a commonality where eventually data will 
be available that enable researchers to show correlations between communities' overall community performance scores and related outputs such as crime, dropout incidence, visitor growth rates, etc.

\section{How Are Items Chosen for Improving Overall Community Performance?}

Respondents from a representative sample in the United States were asked to rate multiple items-as identified in the literature-that could improve the overall performance of a community (Cantrell \& Stafford, 2013). The goal was to determine which of 81 items the respondents thought had the greatest likelihood of improving their community's overall performance. In the three categories identified for improving the overall performance of a community, respondents chose 22 of the 27 neighborhood considerations and 20 of the 27 public service considerations. The public school construct was found to be statistically nonsignificant for increasing the overall performance of the community; however, many of the items in that category represent pivotal considerations for potential homebuyers in most communities.

\section{Neighborhood Modifications That Most Impact Community Improvement}

List 1 shows the neighborhood modifications sample participants felt could most likely improve overall community performance. These modifications mostly reflect better enforcement of ordinances.

\section{List 1. Neighborhood Modifications That Most Impact Overall Community \\ Improvement}

- More stringent, enforceable noise ordinances. These may encourage residents to respect their neighbors' privacy, especially during nighttime hours when most people are sleeping.

- More enforceable vehicle noise ordinances. Such ordinances may discourage neighbors from supplementing their vehicles with accessory items that create loud noises (i.e., deep-bass stereos, exhaust pipes, etc.).

- More enforceable ordinances on the number of vehicles that can be parked on a residential lot. These rules can discourage neighbors from storing more vehicles and accessories on their property than they can use on a routine basis.

- More enforceable animal policing ordinances. Such regulations may require pet owners to be more responsible for where they allow their animal to eliminate.

- More enforceable animal leash ordinances. These may allow residents to move more freely in their neighborhood without concern for personal safety.

- Security cameras installed in undisclosed locations throughout neighborhoods. Cameras may provide assurance that residents are abiding by the ordinances and covenants and that no suspicious activity or strangers are in the neighborhood.

- More stringent neighborhood crime-watch initiatives. These initiatives may help neighbors to know everyone is looking out for everyone else and no suspicious activity or strangers will go unnoticed or unreported.

\section{Neighborhood Modifications That Marginally Impact Community Improvement}

List 2 shows the neighborhood modifications sample participants felt could marginally improve overall community performance. These modifications did not align with any specific theme.

\section{List 2. Neighborhood Modifications That Could Marginally Improve Overall Community Performance}

- Having gated entrances to neighborhoods

- More enforceable grass length/lawn mowing ordinances

- More stringent homeowner associations/more enforceable covenants and deed restrictions

- Restrictions that only allow traditional stick-built construction (no alternative housing)

- Having homeowner associations use private companies to observe conditions of homes in the neighborhoods

- Having websites for homeowner associations

- Not allowing rental properties in the same subdivisions as homeowner properties

- More speed humps/bumps

- More enforceable speed limits

- More speed limit signs

- More portable speed-indicator radar units 
- More sidewalks

- More streetlights

- Having walking/running/bicycle paths

- More public recreation areas

\section{School Considerations That} Nominally Impact Community Improvement

List 3 shows the public school considerations sample participants felt would have little to no improvement on overall community performance.

\section{List 3. Public School Considerations That Have Little to No Impact on Overall Community Improvement}

- Children attending a school located within 20 minutes driving time from home

- Having better maintained schools (inside and outside)

- Having schools better policed or monitored

- Having security cameras located on all school property, including buses

- Having more enforceable programs that separate unmotivated students from motivated students

- Having more stringent and enforceable dress codes

- Having more stringent and enforceable student codes of conduct

- Having regularly scheduled time for citizens to meet with school administrators

- Planning programs that reward parents for visiting classrooms after receiving permission

- Planning programs that reward citizens for volunteering as after-school tutors

- Planning programs that reward schools for hosting industry partners in the school

- Planning programs that reward citizens for judging science fair projects

- Having programs that reward schools for sponsoring events that bring students and citizens together

- Having (or improving) a foreign student-exchange program

- Enabling and allowing all classrooms to access the Internet
- Having programs that enable students to learn lessons from reformed juvenile delinquents

- Planning programs that enable students to learn lessons from recent college graduates

- Having programs that reward students for attending classes on Saturday morning

- Offering onsite after-school programs to supervise students until parents pick them up

- Having required quiet stretching time for all students in the school

- Having required quiet stretching time for all adults in the school

- Dedicating at least 30 minutes for all students and adults in the school to eat lunch

- Requiring all students to perform community service

- Not allowing "junk food" or soda vending machines on school property

- Allowing citizens to use the athletic facilities when not in use

- Having achieving students receive more acknowledgement in the community

- Having achieving teachers and administrators receive more acknowledgement in the community

\section{Public Service Considerations That Most Impact Community Improvement}

List 4 shows the public service considerations sample participants felt could most likely improve overall community performance. These considerations mostly include citizen interaction programs.

\section{List 4. Public Service Considerations That Most Impact Overall Community Improvement}

- More locally sponsored events

- More arts events and performances

- A community information website updated daily

- A well-maintained and patrolled community center

- More youth sports programs

- Having a youth acting (performing arts) program

- Having (or increasing) community-led exercise and nutrition programs 
Public Service Considerations That

Marginally Impact Community

Improvement

List 5 shows the public service considerations sample participants felt could marginally improve overall community performance. These considerations mostly reflect community-sponsored events.

\section{List 5. Public Service Considerations That Could Marginally Improve Overall Community Performance}

- Better landscaped public grounds

- A better maintained and patrolled library

- More community guest speakers

- More adult sports programs

- More town hall meetings

- Having a town historical center

- Having programs that reward citizens for volunteering

- Providing more information on energy conservation topics

- Providing more convenient access to information about University Extension programs

- Providing access to reclaimed water for use in irrigating lawns

- Providing bike lanes on public access routes

- Better recycling services

- Providing a website to make online payments for all services/utilities

\section{Summary}

Minor modifications to neighborhoods, public schools, or public services will not necessarily result in instant improvements in overall community performance. However, when modifications to these areas are considered holistically, the results will become more noticeable over time. As previously mentioned, the public school construct was not statistically significant.

The school items were only measured for public schools and not private, which may have affected the results. It is counterintuitive for citizens (especially if they have at least one minor residing in the home) to not believe that the types of improvements in public schools measured would improve the overall performance of their community. However, it is plausible that citizens and public school systems have grown disconnected as performance requirements have become more stringent in public school systems. Many public school systems have become complex and are difficult to comprehend without actively pursuing knowledge of their mandates and agendas. Citizens may find it easier to simply trust that elected officials are employing tax dollars in an effective and consistent manner according to the needs of students and communities. Thus, research needs to be conducted that further examines whether citizens' trust in their public school systems is warranted.

Successful business models are based on understanding what paying customers desire and then making certain that paying customers understand how it is that they are receiving what they desire. One way to consider tax-paying citizens is as paying customers of public school systems. That means citizens have a right and responsibility to ensure that they understand how they are receiving the services and outcomes desired. The point is not to seek instant results but rather to establish practices aimed at providing citizens with as many of their needs and desires as possible.

\section{References and Resources}

Bennett, T., Holloway, K., \& Farrington, D.P. (2006). Does neighborhood watch reduce crime? A systematic review and meta-analysis. Journal of Experimental Criminology 2(4), 437-458.

Cantrell, R. \& Stafford, A. (2013). The introduction and development of the community-flow measurement instrument. Journal of Community Development. doi:10.1080/155 75330.2012 .761640

Chapman, D.W. \& Lombard, J.R. (2006). Determinants of neighborhood satisfaction in fee-based gated and nongated communities. Urban Affairs Review 41(6), 769-799.

Chavkin, N.F. \& Williams, D.L., Jr. (1987). Enhancing parent involvement: Guidelines for access to an important resource for school administrators. Education and Urban Society 19(2), 164-184.

Crompton, J. (2007). Competitiveness: Parks and open space as factors shaping a location's success in attracting companies, labor supplies and retirees. Economic Benefits of Land Conservation (5).

Durlack, J.A., Berger, S.R., \& Celio, C.I. (2009). "Afterschool programs" In Th.P. Gullotta, M. Bloom, C.F. 
Gullotta, \& J.C. Messina (Eds.), A blueprint for promoting academic and social competence in after-school programs (43-63). New York, NY: Springer.

Emlet, C.A. \& Moceri, J.T. (2012). The importance of social connectedness in building age-friendly communities. Journal of Aging Research. doi:10.1155/2012/173247

Gainesville Police Department. (2012). Residential safety tips. Retrieved from https://www.gainesvillepd.org/index. php?option=com_content\&view=article\&id=74\&Item $\mathrm{id}=87$

Garcia, C.A. (2003). School safety technology in America: Current use and perceived effectiveness. Criminal Justice Policy Review 14(1), 30-54.

Guetzkow, J. (2002). How the arts impact communities: An introduction to the literature on the arts impact studies. Princeton Center for the Arts and Cultural Policy Studies, 1-26. Retrieved from http://www.princeton.edu/culturalpolicy/workpap/WP20\%20-\%20Guetzkow.pdf

Ham, S.A., Kruger, J., \& Tudor-Locke, C. (2009). Participation by U.S. adults in sports, exercise, and recreational physical activity. Journal of Physical Activity and Health 6(1), 6-14.

Jacobs, J. (1992). The death and life of great American cities, second edition. New York: Vintage Books.

Jaworski, B. \& Kohli, A. (1993). Market orientation: Antecedents and consequences. Journal of Marketing 57(3), 53-70.

King, K.A. (2009). Should school uniforms be mandated in elementary schools? Journal of School Health 68(1), 32-37.

Lerchen, E.H. (1978). The parking and storage of trailers and recreational vehicles on the residential premises.

Detroit College of Law Review 457, 458-468. Retrieved from http://heinonline.org/HOL/Page?handle=hein.journals/ mslr1978\&div $=29 \& g \_s e n t=1 \&$ collection $=$ journals

Lukensmeyer, C.J. \& Brigham, S. (2003). Taking democracy to scale: Creating a town hall meeting for the twenty-first century. National Civic Review 91(4), 351-366.

Lynch, K. (1960). The image of the city. Boston: MIT Press.

Menton, C. (2008). Bicycle patrols: An underutilized resource. Policing: An International Journal of Police Strategies and Management 31(1), 93-108.
Morris, D., Shaw, B., \& Perney, J. (1990). Helping low readers in grades 2 and 3: An after-school tutoring program. The Elementary School Journal 91(2), 132-150. Retrieved from http://www.jstor.org/stable/1001747

New York State Energy Research and Development Authority (NYSERDA). (2002). NYSERDA how-to guide to effective energy-efficient streetlighting for municipal elected/appointed officials. Retrieved from http://www.rpi. edu/dept/lrc/nystreet/how-to-officials.pdf

Patel, I.C. (1991). Socioeconomic impact of community gardening in an urban setting. In D. Reif (Ed.), The Role Of Horticulture in Human Well-Being and Social Development: A National Symposium, 84-87.

Perkins, D.F. \& Noam, G.G. (2007). Characteristics of sports-based youth development programs. New Directions for Youth Development 2007(117), 75-84.

Stormwater Ponds. (n.d.). In Northeast Wisconsin Stormwater Consortium. Retrieved from http://www.two-rivers.org/ stormwater/Public\%20Outreach/PondsFAQs.pdf

Timperio, A., Crawford, D., \& Telford, A. (2004). Perceptions about the local neighborhood and walking and cycling among children. Preventive Medicine 38(1), 39-47.

Tucker, D.P. (2012, February 27). In fresh direct move to the Bronx, food delivery to borough not a priority. WYNC News. Retrieved from http://www.wnyc.org/articles/wnycnews/2012/feb/27/fresh-direct-deal-no-requirement-southbronx-food-delivery/

U.S. Environmental Protection Agency, Office of Noise Abatement and Control. (1977). The Urban Noise Survey. Washington, DC: U.S. EPA.

Wells, K. (2011). Better dog laws may lead to healthier communities. Retrieved from http://suite101.com/article/ better-dog-laws-may-lead-to-healthier-communitiesa386026

Whitaker, M. (2012, March 29). In depth: CNN peels back the layers of the Trayvon Martin story. CNN Opinion. Retrieved from http://www.cnn.com/2012/03/29/opinion/ whitaker-in-depth-martin/index.html

Zwerling, E.M. ( 2000). Local government in the 21st century: Exploring the legal issues. Presentation to the International Municipal Lawyers Association, Washington D.C. 